\title{
The effect of website quality and government regulations on online impulse buying behavior
}

\author{
Rina Suthia Hayu ${ }^{a^{*}}$, Surachman ${ }^{b}$, Ainur Rofiq ${ }^{b}$ and Mintarti Rahayu ${ }^{b}$
}

${ }^{a}$ Faculty Economics and Business, University of Bengkulu, Indonesia

${ }^{b}$ Faculty Economics and Business, University of Brawijaya, Indonesia

\begin{tabular}{l}
\hline C H R O N I C L E \\
\hline Article history: \\
Received: September 30, 2019 \\
Received in revised format: No- \\
vember 122019 \\
Accepted: November 12, 2019 \\
Available online: \\
November 12, 2019 \\
\hline Keywords: \\
Web quality \\
Interactive Website \\
Government Regulation \\
Verified Website \\
Online Impulse Buying
\end{tabular}

\section{A B S T R A C T}

\begin{abstract}
The development of information technology has brought the changes to the rapid growth and competition of online website stores in Indonesia. Online store businesses are aggressively making various marketing efforts to influence consumers to shop on their website. The Indonesian government has seriously issued several regulations regarding online commerce or e-commerce since 1997. Thus, this phenomenon has encouraged researchers to analyze the influence of website quality and the application of Government Regulations related to Ecommerce Law through website verification of the behavior of impulse buying, which was conducted by the millennial generation online. This paper presents an empirical investigation to study the effect of website quality and government regulations on online impulse buying behavior among some undergraduate students at Brawijaya Malang University. The results have confirmed that both website quality and government regulations had some impacts on online impulse buying behavior.
\end{abstract}

C 2020 by the authors; licensee Growing Science, Canada

\section{Introduction}

It cannot be denied that the rapid development of information technology especially E-commerce has a substantial influence in changing the landscape of consumer behavior. The availability of 24-hour retail stores through the Internet has led to an increase in the online retail business and certainly an increase in impulse purchases. In fact, impulse buying behavior is very likely to occur, because most consumers make purchases because of their feelings. According to Zaltman (2003) 95\% of a product's purchase decision is based on feelings rather than facts. This is also suitable with the growth of E-commerce and the increase of transaction oriented on consumer (consumer- orientation) which was proposed by Kacen and Lee (2002). A number of researchers have made important contributions to the understanding of impulse buying behavior, (e.g. Stern, 1962; Rook \& Hoch, 1985; Rook, 1987; Rook \& Gardner, 1993; Rook \& Fisher, 1995; Puri, 1996; Beatty \& Ferrell, 1998; Hausman, 2000). Even Stern (1962) identified four types of differences in impulse purchases: a) planned, b) pure, c) reminders, and d) suggestions. Impulsive buying behavior is one of the most popular research topics among the consumer researchers today to address the causes, driving forces and triggers of impulsive buying behavior. This reality is reinforced by the era in which we live now, and shopping has been identified as a form of recreational activity (Enrico et al., 2014). Through the internet, the opportunity of purchases for consumer has been expanded through increased accessibility for products and services to increase the convenience in making purchases. This fact is reinforced by research conducted by Totonchi and Kakamanshadi (2011) which stated that the adoption of Information Communication and Technology (ICT) has grown by reducing transaction costs and coordination and creating new market and expanded with an economic scale. Based on the results of the Boston Consulting Group (BCG) survey, in 2013 published on the page www.wartaekonomi.co.id, the middle class in Indonesia reached 74

* Corresponding author.

E-mail address: rinahayu5515@gmail.com (R. S. Hayu) 
million people and predicted in 2020 it would rise to 141 million people or around $54 \%$ of the total population in Indonesia. Seeing this data, it is clear and certain that the market potential of E-commerce in Indonesia is very large. Nielsen Global ECommerce and the New Retail Survey, Q3 (2014) also revealed the demographic side, enthusiasts of online shopping in Indonesia are still dominated by women with a percentage reaching 53 percent, which 56 percent are still young, around 1830 years. The survey results also found that the millennial generation and $\mathrm{Z}$ generation aged 15-34 were the group who mostly make online purchases. This means that these consumer groups also make the most online impulse buying. Thus, online business or E-commerce has become a trend and a need in the future. The companies increasingly conduct business activities with a wider target market by utilizing information and communication technology through the internet and provide attractive, informative and persuasive web quality. The better the quality of the web, the higher the level of possibility of impulse buying (Jones \& Leonard, 2008). Of course, this phenomenon is not immune from government oversight, which must carefully and quickly give fair and transparent regulations for both online business people and online business consumers. So far, the government has issued Law Number 8 of 1999 concerning Consumer Protection and Government Regulation Number 82 of 2012 concerning the Implementation of System and Electronic Transactions. The law is derived from Law Number 11 of 2008 concerning Information and Electronic Transactions. The absence of previous studies regarding the application of government regulations related to the E-commerce Law on the behavior of online impulse buying in Indonesia has created a gap to conduct this research. Government Regulations related to E-commerce Law become a new variable that will contribute for the development of online impulse buying behavior in the field of marketing science.

Effective website design is an important key for the success of electronic commerce, ranging from functionality, usability, ease of navigation and interface of the site itself, is very important for sustained success (Constantinides, 2004; Yen et al., 2007; Lim et al., 2008, Deng \& Poole, 2012). Another study, revealed the effects of atmospheric variables on consumer behavior and satisfaction, Klopping and McKinney (2004) found that a set of atmospheric variables contributed to the satisfaction of all consumers. Variables related to special offers / coupons, product descriptions, graphics/photos/images, product prices, total product costs, options to delete previously selected items, service/toll free numbers for customer service, and order confirmation via e -mail. According to Rayport and Jaworski (2003) effective websites displayed seven design elements called 7C, namely: a) Context: layout and design. b) Content: text, images, sounds, and videos that are on the website. c) Community: how the site allows communication between users. d) Customization: Site capability to deliver itself to various users or allow users to personalize the site. e) Communication: how sites allow communication of sites with users; user with the site; or two-way communication. f) Connection: the level of connection of the site with other sites. g) Commerce: The ability of sites to allow commercial transactions.

Presently, several regulations have been applied in Indonesia associated with online business, especially in their use to carry out buying and selling transactions, namely: 1) E-commerce, Trade through the Electronic System is currently regulated in Article 65 of Law Number 7 of 2014 concerning Trade (Trade Law). Basically, the provisions of the Trade Law require Businessman who trade goods and / or services by using electronic systems to provide data and/or complete and correct information. 2) Business Entity Legal Status (Permits and Requirements). As a technology or software company, the permits and requirements that it has are a Trading Business License and Company Registration Certificate. Application technology operators as connecting businessmen do not need to have permission to trade in goods and services that they connect through application technology. This is because the responsibility for the trade in goods and services is in the producers of goods and services. 3) Consumer Protection. From the perspective of Consumer Protection Law, in the scheme of goods selling and buying activities and/or through application technology with electronic systems, the responsibility of Businessmen can be classified as the responsibility of Business Providers of Goods and / or Services, and Application Technology Business Players that connect the selling and buying activities. The importance of understanding impulse buying in retail stores was first identified in the marketing literature more than fifty years ago (Clover 1950). Impulse purchases gave significantly to products sold in various product categories (Hausman, 2000; Rook \& Fischer 1995). Impulse buying has been studied from different perspectives in consumer, economic, social and psychological studies. Bas Verplanken and Ayana Sato (2011b) explained impulse buying as a pleasant behavior, which can occur due to positive emotions. A decade after Clover's (1950) initial research on impulse purchases, Stern (1962) followed by finding four types of impulse purchases, namely; pure, reminders, suggestions, and planned impulse purchases. Stern (1962) made a significant contribution, because even today most research studies use the concept of impulse buying as the starting point of the theory (Beatty \& Ferrell, 1998; Rook, 1987). William (1951) introduced the concept of stimulus exposure into the concept of impulse buying, and defined impulse buying as purchases not planned by the customer before entering the store, but which resulted from the stimulus created by the store's sales promotion. Research on impulse buying has been based on various conceptual definitions of the construct and has been focused primarily on retail stores. But in this study, as the development advanced in communication and information technology, this study tried to expand the concept of impulse buying on online purchases on the Internet through the provision of stimulus. The quality of website is an important and widely studied factor in E-commerce literature (Aladwani \& Palvia, 2002; Soliman \& Youssef, 2003). Liu and Arnett (2000) revealed that four factors are very important for the success of a website in Ecommerce: information quality, usage system, fun and quality of system design. Barnes and Vidgen (2000) argued that WebQuery must be used to evaluate websites from a customer perspective that can be overcome through four components: function, content, service and attractiveness. This research was limited to analyze the focus on online impulse buying behavior decisions. In the context of online shopping, buying behavior could be seen as a response made by individuals as an impact of certain stimulus. This refers to the concept or model of the S-O-R paradigm (Stimulus-Organism-Response) described by 
Mehrabian and Russell (1974) and Russell and Pratt (1980). The S-O-R theory stated that a stimulus (S) influences a person's internal being evaluated affective $(\mathrm{O})$, which in turn causes a response to approach or avoid (R). In other words, people react to environment influences (approach behavior) positive or negative, ways (avoidance behavior). In the regulation of online buying, the theory of S-O-R turns out to be the right lens of theory to understand how web-based stimuli influence online consumer behavior (Deng \& Poole, 2012; Xu \& Huang, 2014, Li et al., 2011).

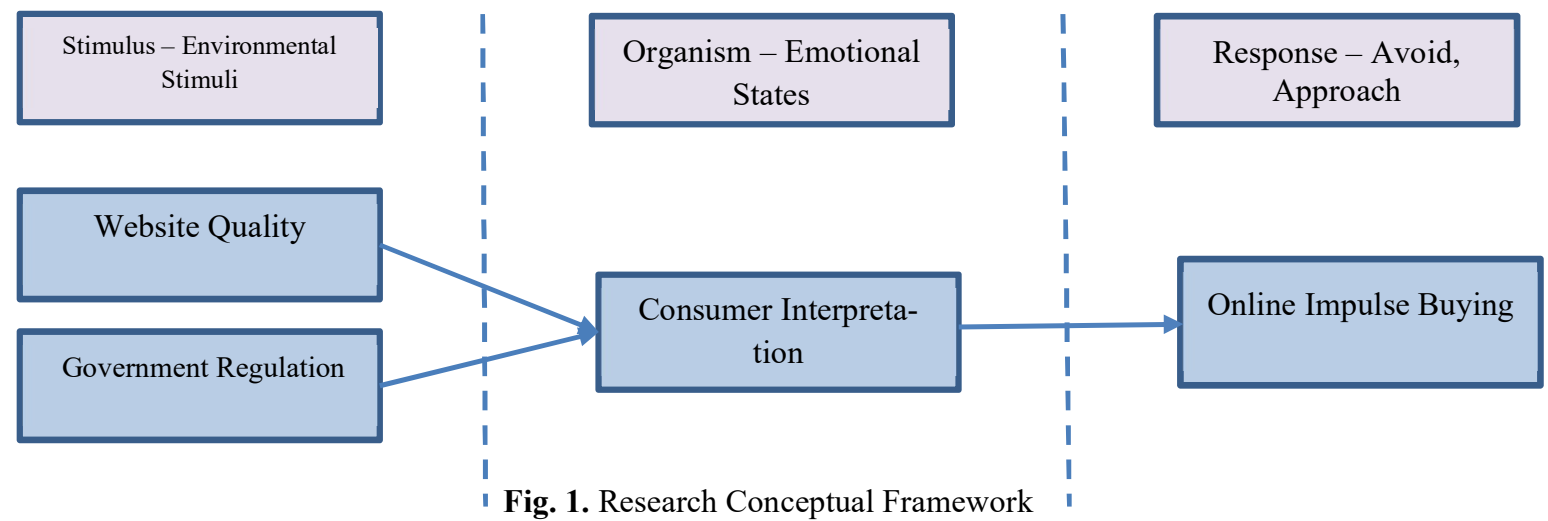

The SOR model in this study illustrated how online consumer behavior when receiving a stimulus developed becomes a particular response. Rhee (2006) demonstrated that a website may have some influential impacts on buying behavior due to large expansion of website pages in the world, which are available 24 hours a day, seven days a week. A decision to purchase a particular product or service may happen in less than a minute so it is important to attract the consumer's attention through beautiful web design (Brohan, 1999). The decision of the Government of the Republic of Indonesia issued Legislation which arranges E-commerce business through Law No. 7 of 2014 concerning Trade which is the legal basis for the organizer of Trade Through Electronic Systems and consumers in trading activities via the electronic system needs more attention for academics and practitioners. Therefore, in this study, the authors analyzed the paradigm shift in online consumer behavior which also affects the online behavior of impulse buying. Government issued legislation related to Ecommerce, of course, cannot be separated from the observation and review of the facts of the development of e-commerce in Indonesia. Various websites that are addictive, and not in accordance with regulatory content in E-commerce, further strengthen government regulations in providing protection for consumers. Of course, the various objectives of implementing the constitution of Ecommerce will affect how consumers will respond, be motivated and have a better perception when suddenly making impulse buying in an online store and continue for a long time. Then the second hypothesis that the author's propose in research this is Government Regulations Influence on Online Impulse buying.

\section{Method}

The research method used was a quantitative method based on the positivism paradigm, using experimental research (Nahartyo \& Utami 2016). The objective is to present the empirical evidence for a theory that explains and predicts the phenomenon of causality relationships described earlier. The authors want to show empirical evidence from existing impulse buying theories regarding the quality of websites and provide empirical evidence on the presence of the phenomenon of the enactment of E-commerce Law No. 7 of 2014 on the behavior of online impulse buying. The use of the internet as a marketing research tool is relatively new and marketing researchers should learn how to use the internet as a research tool (Furrer et al., 2000). A typology of internet marketing research can be designed through three-dimensional construction, namely: 1) Survey object, 2) Sample unit or participant, 3) Method of collecting data. Participants in this study were 175 people as students of the Faculty of Economics and Business, Bachelor Degree, management department at Brawijaya University, Malang. Students are often chosen as subjects of research in psychology and marketing experiments. This practice is convenient for researchers who generally work at universities, but this practice cannot fully generalize findings because the limited responses from students to impulse buying may not be representative of the total population of people (Kantowitz et al., 2009). This experimental sample was controlled through randomization, which randomly distributed samples in the experimental group and group control.

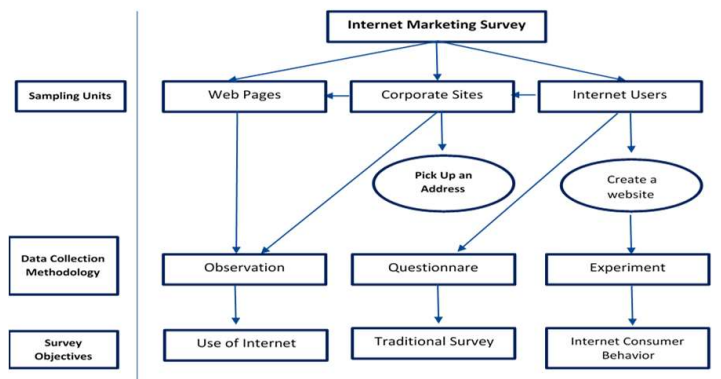

Fig. 2. Typology of Internet Marketing Research 
This experimental study used a sample design between subjects (between - subject design), in this way each subject will get one manipulation of the factors studied. The research instrument used four types of websites as a stimulus, namely:

1. Interactive Website, designed with the name www.pamathan.com. Website with interactive web quality has indicators of complete information availability, transaction security, ease of use of Website, convenience in accessing and the best quality of service as a form of feedback for online consumers.

2. Not Interactive Website, designed with the name www.monggomlebu.xyz. Websites with less interactive web quality, both in terms of design, information content, transaction security, convenience, comfort, service quality.

3. Websites that have followed Government Regulations as well as interactive website, are designed with the name www.pamathanshop.com. This website is designed as a website that has implemented Government Regulations related to E-commerce Law No. 7 of 2014 which are displayed on an interactive website and symbolized by the Verified Logo by KEMENKOMINFO.

4. Websites that have followed Government Regulations but are less attractive, are designed with the name www.doradori.xyz. This website is a website designed to implement government regulations related to E-commerce Law No. 7 of 2014 but is displayed on a less interactive website and symbolized by the Verified Logo by KEMENKOMINFO.

This study used true experimental design with the main characteristics of being able to explicitly manipulate one or more independent variables and classify participants' subjects into control or experimental groups to achieve rendering (Ghozali, 2013). A laboratory experiment was used to investigate hypotheses in this study. In the laboratory, researchers could control most foreign variables. These characteristics were very important to ensure internal validity and examine the effects of causality (Lynn \& Lynn, 2003). Laboratory experiments also had more structured procedures so that the results obtained will be more reliable (have higher reliability). This study had two factors A and B, and each had two levels: A1 and A2 and B1 and B2, so the factorial design would contain all AB combinations. Treatment A consisted of the implementation of Government Regulation related to E-commerce No. 7, 2014 on the website which was marked by the verification of KEMENKOMINFO and not the implementation of Government Regulations related to E-commerce No. 7, 2014 marked by the absence of KEMENKOMINFO verification symbol (10). Treatment B consists of interactive website and not interactive website $\left(\begin{array}{ll}1 & 0\end{array}\right)$.

The implementation of the true experiment consists of several stages, starting from the management of permits to the laboratory, permission to use participants to the promoters and co-promotor, dividing the participant class, explaining the purpose of the experiment and introducing the self, dividing participants' schedules based on their respective cells / groups, giving stimulus. Based on their respective groups, participants accessed the web according to their respective groups, all participants filled in their respective data according to the group, participants filled the shopping basket and filled out the experimental questionnaire, participants filled out the check manipulation and experimental questionnaire, participants finished filling out the experimental questionnaire online. Also, participants were allowed to go home and given souvenirs. The data used were primary and secondary data types. Primary data was collected through laboratory experiments. Secondary data were obtained from literature search in the form of evidence, notes, or historical reports arranged in archives, both published and unpublished, which were related to impulse buying, especially the literature on web quality and government regulations.

Measurement of the data used in this study was with a 5-point Liker scale. Participants gave answers, in the positive range to negative. Participants who gave a score of 5 meant that participants' perceptions were very positive, whereas if participants gave a score of 1 , the participant's perception was very negative. This experimental research began by conducting a research instrument test through validity and reliability testing first, after that we have conducted the test and analysis of manipulation checks from all the answers of the experimental participants. If the correlation in this study is positive and the amount is 0.3 and above, then the instrument has good validity and is considered a strong instrument construction.

Reliability testing in this study used Cronbach's alpha, because Cronbach's alpha test is a technique of reliability testing of the most frequently used questionnaires, according to Sekaran and Bougie's opinion (2010). Reliability test results with the value of Cronbach's Alpha $>0.5=$ Reliable this is in accordance with the opinion of Ghozali (2013), and Ferdinand (2002). Creswell (2012) emphasized that the key characteristic of experimental research is: random placement of participants (random assignment), so that research results can be generalized to the population. In essence, experimental research is research by manipulating, controlling variables and observing variables. If necessary, adjustments can be made, before conducting large-scale research with greater investment resources (Myers \& Hansen, 2012). In this study, one-way ANOVA was chosen to compare the mean of two independent variables at the stage of manipulation check.

\section{Results}

\subsection{Validity test}

Table 1 demonstrates the results of correlation test. As we can observe, all components are reliable. 
Table 1

Test Results for Real Validity Experiments

\begin{tabular}{|c|c|c|c|c|c|c|c|}
\hline \multicolumn{4}{|c|}{ Web Quality Validity Test Results } & \multicolumn{4}{|c|}{ Test Results for Validity of Government Regulations } \\
\hline Question & Correlation Coefficient & $\mathrm{r}$ table & Result & Question & Correlation Coefficient & $\mathrm{r}$ table & Result \\
\hline Question 1 & 0.681 & 0.1484 & Valid & Question 1 & 0.820 & 0.1484 & Valid \\
\hline Question 2 & 0.667 & 0.1484 & Valid & Question 2 & 0.817 & 0.1484 & Valid \\
\hline Question 3 & 0.652 & 0.1484 & Valid & Question 3 & 0.864 & 0.1484 & Valid \\
\hline Question 4 & 0.661 & 0.1484 & Valid & Question 4 & 0.871 & 0.1484 & Valid \\
\hline Question 5 & 0.604 & 0.1484 & Valid & Question 5 & 0.748 & 0.1484 & Valid \\
\hline Question 6 & 0.738 & 0.1484 & Valid & Question 6 & 0.741 & 0.1484 & Valid \\
\hline Question 7 & 0.751 & 0.1484 & Valid & \multicolumn{4}{|c|}{ Validity Test Results Online impulse buying } \\
\hline Question 8 & 0.623 & 0.1484 & Valid & Question 1 & 0.641 & 0.1484 & Valid \\
\hline Question 9 & 0.716 & 0.1484 & Valid & Question 2 & 0.581 & 0.1484 & Valid \\
\hline Question 10 & 0.774 & 0.1484 & Valid & Question 3 & 0.616 & 0.1484 & Valid \\
\hline Question 11 & 0.618 & 0.1484 & Valid & Question 4 & 0.412 & 0.1484 & Valid \\
\hline Question 12 & 0.714 & 0.1484 & Valid & Question 5 & 0.530 & 0.1484 & Valid \\
\hline Question 13 & 0.677 & 0.1484 & Valid & Question 6 & 0.418 & 0.1484 & Valid \\
\hline
\end{tabular}

Source: data processed by researcher

\subsection{Reliability Test}

Reliability testing is used to determine the consistency of indicators in measuring the intended latent variable and the results are shown in Table 2. As we can observe all components are reliable.

Table 2

Reliability Test Results

\begin{tabular}{llll}
\hline Variable & Reliability Coefficient & Limit & Result \\
\hline Government Regulation & 0.896 & 0.5 & Reliable \\
Kualitas Web & 0.902 & 0.5 & Reliable \\
Online impulse buying & 0.845 & 0.5 & Reliable \\
\hline
\end{tabular}

Source: data processed by researcher

\subsection{Manipulation Check}

The manipulation check is the initial key to an experimental study, if many participants or participants fail in this manipulation check, then the participant must be excluded and cannot be processed further in the next experimental stage. Table 3 shows the results of ANOVA factorial manipulation check with coding $\left(\begin{array}{ll}0 & 1\end{array}\right)$ that has been conducted:

Table 3

ANOVA Factorial Manipulation Check

\begin{tabular}{|c|c|c|c|c|c|}
\hline Source of Diversity & $\mathrm{Db}$ & $\mathrm{JK}$ & KT & F Calculate & Significance \\
\hline $\mathrm{W}$ & 1 & 1779.22 & 1779.22 & 8904.89 & 0.000 \\
\hline PP & 1 & 1.85 & 1.85 & 9.27 & 0.002 \\
\hline Interaction & 1 & 3.86 & 3.86 & 19.33 & 0.000 \\
\hline Error & 696 & 139.06 & 0.20 & & \\
\hline Total & 699 & 1924.00 & & & \\
\hline
\end{tabular}

The results of the manipulation check show that there was a significant effect on the quality of the web and the application of government regulations and there was some online impulse buying. Regression equations obtained based on randomized design factorial are as follows:

$\mathrm{Y}=2.4000-1.5943 \mathrm{~W} 1+1.5943 \mathrm{~W} 2-0.0514 \mathrm{PP} 1+0.0514 \mathrm{PP} 2+0.0743 \mathrm{~W} 1 \times \mathrm{PP} 1-0.0743 \mathrm{~W} 1 \times \mathrm{PP} 2-0.0743 \mathrm{~W} 2 \times$ $\mathrm{PP} 1+0.0743 \mathrm{~W} 2 \times \mathrm{PP} 2$

This means that the manipulation check at the true stage of this experiment has passed and all participants' answers can be continued to be processed in the hypothesis test stage.

\subsection{Hypothesis Testing}

Fig. 3 shows the test result of Hypothesis 1 (H1) and hypothesis 2 (H2) for Website Quality variables and the application of Government Regulations related to E-Commerce which are symbolized by a sign of Verification by KEMENKOMINFO. 


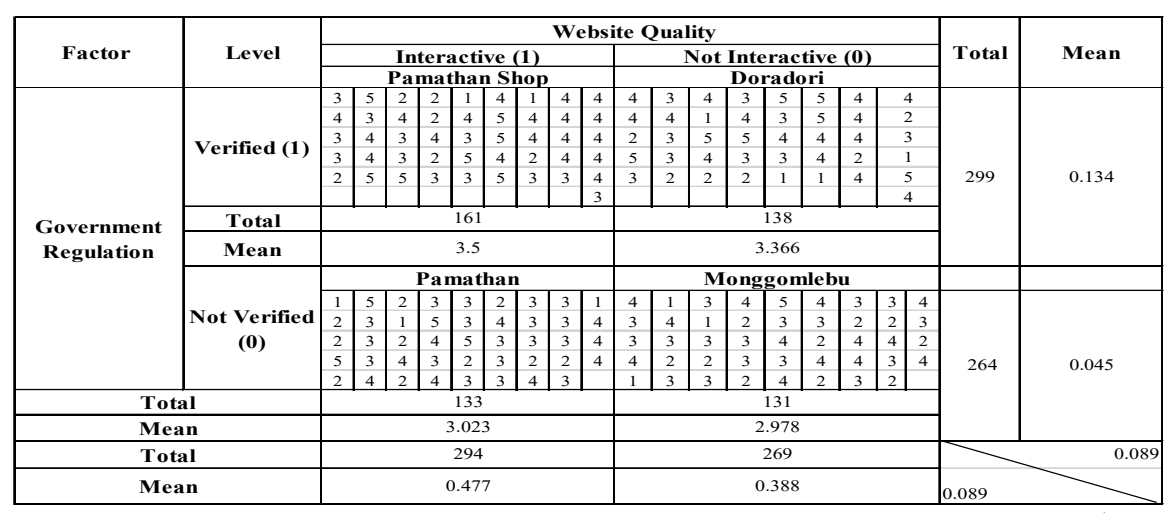

Fig. 3. Experimental Matrix of Factorial Randomized Design

Based on the results of experiments that have been conducted, it was known that the highest mean was obtained in cell 1, namely for the website www.pamathanshop.com where this website was included in the interactive website category and has been verified by KEMENKOMINFO, with an average of 3.5 and the simple effect of 0.134 on the website www.doradori.xyz which was included in the interactive website category but was verified by KEMENKOMINFO with an average of 3.366 . This fact is further strengthened by the results of the mean obtained by cell 3 and cell 4, namely for the website www.pamathan.com which fallen into the category of interactive and unverified government (cell 3) had a mean of 3.023 which was lower than the mean cell 2, www.doradori.xyz, even though Doradori was not a website that was too interactive like pamathan.com, but the power of doradori was that the aspect was verified by the government. Especially when compared with the results of the mean in cell 4, namely for the website www.momggomlebu.xyz, the lowest mean value was 2.978 and had a simple effect on pamathan.com was 0.045 . Then to obtained the regression equation on this true experiment based on the factorial randomized design that has been designed, then we have performed the General Linear Model analysis: Response versus Web Quality, Government Regulation with the results of Regression Equation as follows:

Response $=3.2165+0.0449 \mathrm{KW} \_1-0.0449 \mathrm{KW} \_2+0.2165$ PP_1 -0.2165 PP_2 $+0.0222 \mathrm{KW} \times$ PP_1 $1-0.0222 \mathrm{KW} \times$ PP_1 $2-0.0222 \mathrm{KW} \times$ PP_2 $1+0.0222 \mathrm{KW} \times$ PP_-2 2

From a series of experiments that have been carried out, we may conclude that Hypothesis 1 (H1), namely the quality of websites influenced online impulse buying was proven. Moreover, it is evident that the stimulus or treatment of A factor in cell 1, namely www.pamathanshop.com occupies the highest value that affected the behavior of online impulse buying of participants with a mean cell was 3.5 , the value of the simple effect was 0.134 on the website www.doradori.xyz and the main effect value was 0.089. Likewise, in the second hypothesis (H2), namely Government Regulation related to E-commerce as indicated with verification by KEMENKOMINFO influenced the online impulse buying of participants was also evident in this experiment, which was indicated by the average value of cell 2 namely on the web stimulus www.doradori .xyz and the cell average value (mean) was higher than the www.pamathan.com web which was included in the interactive category but has not been verified by KEMENKOMINFO which was 3.366 with a simple effect of 0.343 and the main effect value was 0.089 .

\section{Discussion}

Although the booming E-commerce market has led to impulsive buying, however few studies have explored impulse buying through websites or online shopping sites. Therefore, academic and managerial interests have increased in terms of factors that encourage spontaneous buying among consumers in the E-commerce environment. Some studies on impulse buying has been based, in particular, on the architectural quality of the website (Verhagen \& van Dolen, 2011a; Liu et al., 2013; MasMachuca et al., 2016). Therefore, the first hypothesis (H1) in this study through the experimental method has examined the strength or influence of the quality of a website on consumers' online impulse buying behavior, and the results are proven. The results of this study have strengthened the results of previous studies conducted by Kim and Niehm (2009), Liu et al. (2013), Moez (2013), Floh and Madlberger (2013) and Lin and Lo, (2015). All researchers generally agreed to say that in online impulse behavior influenced by the presence of a quality website, attractive and effective design elements (for example, virtual layout) have often been used to influence consumer impulse buying behavior online. According to Wells et al. (2011) online impulse buying is the result of stimuli that cause people to behave impulsively. This is the same as the opinion of Floh and Madlberger, (2013), who also agree on the behavior of online impulse buying, so that the results of these stimuli cannot be interpreted exclusively as personal traits that will apply equally to everyone. Online store design factors and sales promotion stimuli are an important beginning of online impulse buying. Website navigation, visual appeal, and diversion safety in all atmospheric cues that can directly influence the possibility that consumers will experience purchase impulses (Wells et al., 2011). Verhagen and van Dolen, (2011b), Liu et al., (2013) also conducted research focusing on environmental factors and promotion to explore how environmental conditions affect impulse buying behavior. Similar with the research that has been 
conducted; this study adopted the Stimulus-Organism-Response (S-O-R) model to investigate the effects of external environmental factors. Variable of Government Regulation related to E-commerce in Indonesia, especially in the implementation of Law No. 7 of 2014 for online business people operating in Indonesia is a new variable that the researchers tried to raise in this study. In order to achieve the government's aspiration to be able to compete in the world of E-commerce both locally, globally and internationally, it is important that the government verify all online business units based on websites or online shop sites that are actively operating in the Indonesian territory. This will not only increase the security of transactions and online consumer trust in making online purchases domestically, but also will affect the competitive ability of online businesses in the international market, so that the market target is achieved not only in the local market, but also global and international markets. The government's ability to verify the website of online business entrepreneurs in Indonesia will affect them in making impulse shopping decisions, and this has been proven through research conducted experimentally among teenagers in Malang. The results of this study have also been able to answer the challenges of impulse buying theory classification proposed by Stern (1962) which stated that impulsive buying could be created by providing certain conditions namely stimuli and even the creation of engineered environmental or governmental regulations.

The practical implications of this study are: 1) This discovery provided new contributions that could be applied by the government through website verification efforts to all online business units operating in Indonesia in order to support the Ecommerce map and the application of Government Regulation on E-commerce (Law No. 7 of 2014 concerning Trade) to achieve an increase in the quality and quantity of Indonesian E-commerce transactions for both domestic, global and international markets. Of course, this verification will be a source of new funding for the government to increase state income. 2) For practitioners, namely online business people should improve the quality of websites or online shopping sites that already exist, because it is proven by Indonesian online consumers, the majority of which are dominated by teenagers, getting smarter in choosing websites, online sites or market places. This study had limitations including: 1) The scope of this research sample was only limited to students of bachelor degree, Department of Management, Faculty of Economics and Business, Brawijaya University. But the results of the research have shown an overview of online shopping behavior related to impulse buying which represented an overview of online shopping behavior of teenagers in Malang City in particular and Indonesia in general. The results of this study were also in accordance with the results of previous studies, and reinforced by the official report on the statistical data of the Ministry of Communication and Information Republic of Indonesia which showed online shopping behavior patterns in Indonesia in 2015 and 2016. 2) Experiments were conducted in the laboratory in several sessions still constrained website access speed and voltage was sometimes less stable.

\section{Conclusion}

This research has provided renewal of the research concept and the results that have been done with the experimental method, namely proving that website quality and website verification conducted by KEMENKOMINFO could increase the tendency of online consumers to make impulse buying. Some of the suggestions that can be put forward in this study are: 1) The Indonesian government, especially KEMENKOMINFO, are suggested to implement verification website or online shopping sites in Indonesia, because this will be a new innovation strategy in achieving the government's aspiration to realize Indonesia as the largest digital economy country in Southeast Asia in 2020 through convenience and updating E-commerce usage. 2) For online business people, they should be able to create an interactive and verified website by KEMENKOMINFO to be able to compete in the Ecommerce market so that they are more capable of competing in increasingly fast-growing digital business. 3) As the development of further research, since this is the first research (basic research experiment), it should be able to dig new items or indicators in reviewing government regulation variables related to E-commerce, with more samples and participants.

\section{References}

Aladwani, A. M., \& Palvia, P. C. (2002). Developing and validating an instrument for measuring user-perceived web quality. Information \& management, 39(6), 467-476.

William, A. (1951). Studying consumer behavior in retail stores. Journal of Marketing, 16, 32-40.

Barnes, S., \& Vidgen, R. (2000). WebQual: an exploration of website quality. ECIS 2000 Proceedings, 74.

Beatty, S. E., \& Ferrell, M. E. (1998). Impulse buying: Modeling its precursors. Journal of Retailing, 74(2), 169-191.

Brohan, M. (1999). Gotta Have It. Internet Retailer, Available At: www.Internetretailer.com

Clover, V. T. (1950). Relative importance of impulse-buying in retail stores. Journal of Marketing, 15(1), 66-70.

Constantinides, E. (2004). Influencing the online consumer's behavior: the Web experience. Internet Research, 14(2), 111-126.

Creswell, J. W. (2012). Educational research: planning. Conducting, and Evaluating.

Deng, L., \& Poole, M. S. (2012). Aesthetic design of e-commerce web pages-Webpage Complexity, Order and preference. Electronic Commerce Research and Applications, 11(4), 420-440.

Enrico, A., Aron, R., \& Oktavia, W. (2014). The Factors That Influenced Consumptive Behavior. A Survey of University Students in Jakarta. International Journal of Scientific and Research Publications, 4(1), 1-6.

Ferdinand, A. (2002). Structural Equation Modelling. Dalam Penelitian Management, Semarang: FE UNDIP.

Floh, A., \& Madlberger, M. (2013). The role of atmospheric cues in online impulse-buying behavior. Electronic Commerce Research and Applications, 12(6), 425-439. 
Ghozali, I. (2013). Aplikasi Analisis Multivariat dengan Program IBM SPSS 21. Edisi 7, Penerbit Universitas Diponegoro, Semarang. Quarterly Journal of Economics, 128, 1547-1584.

Hausman, A. (2000). A multi-method investigation of consumer motivations in impulse buying behavior. Journal of Consumer Marketing, 17(5), 403-426.

Kim, H., \& Niehm, L. S. (2009). The impact of website quality on information quality, value, and loyalty intentions in apparel retailing. Journal of Interactive Marketing, 23(3), 221-233.

Jones, K., \& Leonard, L. N. (2008). Trust in consumer-to-consumer electronic commerce. Information \& management, 45(2), 8895.

Kacen, J. J., \& Lee, J. A. (2002). The influence of culture on consumer impulsive buying behavior. Journal of consumer psychology, 12(2), 163-176.

Kantowitz, B. H., Roediger, I. H. L., \& Elmes, D. G. (2009), Experimental Psychology, $9^{\text {th }}$ ed., Wadsworth, Belmont.

Klopping, I. M., \& McKinney, E. (2004). Extending the technology acceptance model and the task-technology fit model to consumer e-commerce. Information Technology, Learning \& Performance Journal, 22(1).

Lim, E. A. C., \& Ang, S. H. (2008). Hedonic vs. utilitarian consumption: A cross-cultural perspective based on cultural conditioning. Journal of business research, 61(3), 225-232.

Lin, S. W., \& Lo, L. Y. S. (2016). Evoking online consumer impulse buying through virtual layout schemes. Behaviour \& Information Technology, 35(1), 38-56.

Liu, Y., Li, H., \& Hu, F. (2013). Website attributes in urging online impulse purchase: An empirical investigation on consumer perceptions. Decision Support Systems, 55(3), 829-837.

Lynn, A., \& Lynn, M. (2003). Experiments and quasi-experiments: Methods for evaluating marketing options. The Cornell Hotel and Restaurant Administration Quarterly, 44(2), 75-84.

Mas-Machuca, M., Berbegal-Mirabent, J., \& Alegre, I. (2016). Work-life balance and its relationship with organizational pride and job satisfaction. Journal of Managerial Psychology, 31(2), 586-602.

Mehrabian, A., \& Russell, J. A. (1974). An approach to environmental psychology. the MIT Press.

Ltifi, M. O. E. Z. (1970). Antecedents and effect of commitment on the impulse buying by internet. The Journal of Internet Banking and Commerce, 18(1), 1-22.

Myers, A., \& Hansen, C. H. (2011). Experimental psychology. Cengage Learning.

Nahartyo, E., \& Utami, I. (2016). Panduan Praktis Riset Eksperimen. Jakarta: PT. Indeks.

Furrer, O., Liu, B. S. C., \& Sudharshan, D. (2000). The relationships between culture and service quality perceptions: Basis for cross-cultural market segmentation and resource allocation. Journal of service research, 2(4), 355-371.

Puri, R. (1996). Measuring and modifying consumer impulsiveness: A cost-benefit accessibility framework. Journal of consumer Psychology, 5(2), 87-113.

Rayport, J. F., \& Jaworski, B. J. (2002). Introduction to e-commerce. McGraw-Hill/Irwin marketspaceU.

Rhee, Y. J. (2006). Online impulse buying behavior with apparel products: Relationships with apparel involvement, website attributes, and product category/price (Doctoral dissertation, Virginia Tech).

Rook, D. W. (1987). The buying impulse. Journal of consumer research, 14(2), 189-199.

Rook, D. W., \& Hoch S. J. (1985). Consuming impulses. Advances in Consumer Research, 12, 23-27.

Rook, D. W., \& Gardner, M. P. (1993). In the mood: Impulse buying's affective antecedents. Research in consumer behavior, 6(7), $1-28$.

Rook, D. W., \& Fisher, R. J. (1995). Normative influences on impulsive buying behavior. Journal of consumer research, 22(3), 305313.

Russell, J. A., \& Pratt, G. (1980). A description of the affective quality attributed to environments. Journal of Personality and Social Psychology, 38(2), 311-322

Soliman, F., \& Youssef, M. A. (2003). Internet-based e-commerce and its impact on manufacturing and business operations. Industrial Management \& Data Systems, 103(8), 546-552.

Stern, H. (1962). The significance of impulse buying today. Journal of Marketing, 26(2), 59-62.

Totonchi, J., \& Kakamanshadi, G. (2012). Relationship between globalization and e-commerce. International Journal Of E-Education, E-Business, E-Management And E-Learning, 2(1).

Verhagen, T., \& van Dolen, W. (2011a). The influence of online store beliefs on consumer online impulse buying: A model and empirical application. Information \& Management, 48(8), 320-327.

Verplanken, B., \& Sato, A. (2011b). The psychology of impulse buying: An integrative self-regulation approach. Journal of Consumer Policy, 34(2), 197-210.

Wells, J. D., Parboteeah, V., \& Valacich, J. S. (2011). Online impulse buying: understanding the interplay between consumer impulsiveness and website quality. Journal of the Association for Information Systems, 12(1), 3.

$\mathrm{Xu}$, Y., \& Huang, J. S. (2014). Effects of price discounts and bonus packs on online impulse buying. Social Behavior and Personality: an international journal, 42(8), 1293-1302.

Yen, B. P. C. (2007). The design and evaluation of accessibility on web navigation. Decision Support Systems, 42(4), $2219-2235$.

Zaltman, G. (2003). How customers think: Essential insights into the mind of the market. Harvard Business Press.

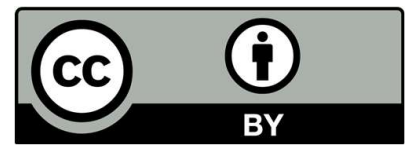

(C) 2020 by the authors; licensee Growing Science, Canada. This is an open access article distributed under the terms and conditions of the Creative Commons Attribution (CCBY) license (http://creativecommons.org/licenses/by/4.0/). 